\title{
Microsatellite markers for assessing genetic diversity of the medicinal plant Paris polyphylla var. chinensis (Trilliaceae)
}

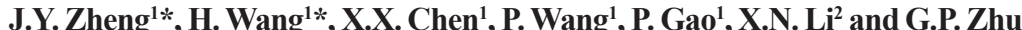

${ }^{1}$ Key Laboratory of Molecular Evolution and Biodiversity, Institute of Molecular Biology and Biotechnology,

Anhui Normal University, Wuhu, P.R. China

${ }^{2}$ Yijishan Hospital, Wannan Medical College, Wuhu, P.R. China

*These authors contributed equally to this study.

Corresponding author: G.P. Zhu

E-mail: gpz1996@yahoo.com

Genet. Mol. Res. 11 (3): 1975-1980 (2012)

Received June 22, 2011

Accepted December 12, 2011

Published August 6, 2012

DOI http://dx.doi.org/10.4238/2012.August.6.1

\begin{abstract}
Paris polyphylla var. chinensis is a perennial herb with medicinal properties that is widely used in traditional Chinese medicine. However, this plant has been on the edge of extinction during the last few decades because of excessive deforestation based on the intense ethnopharmaceutical interest. We isolated 12 microsatellite loci from a (CT) -enriched genomic library of $P$. polyphylla var. chinensis. The polymorphism at each locus was analyzed by screening 30 individuals from a natural population. The number of alleles ranged from 2 to 5 . The observed and expected heterozygosities ranged from 0.000 to 0.467 , with a mean of 0.247 , and from 0.383 to 0.662 with a mean of 0.537 , respectively. Six loci $(P p 1, P p 3, P p 6, P p 7, P p 9$, and $P p 12$ ) were found to significantly deviate from Hardy-Weinberg equilibrium. This may be due to the small population size, inbreeding or null alleles. Five of the pairwise comparisons $(P p 1$ and $P p 4, P p 2$ and $P p 5, P p 2$ and $P p$ 9, $P p 2$ and $P p 12, P p 11$ and $P p 12)$ exhibited significant
\end{abstract}


linkage disequilibrium $(\mathrm{P}<0.05)$. We conclude that these microsatellite markers will be useful for population genetic studies of $P$. polyphylla var. chinensis.

Key words: Paris polyphylla var. chinensis; Microsatellite; Molecular marker; Population genetics

\section{INTRODUCTION}

Paris is the botanical name of a genus of flowering plants with a thickened rhizome. The genus includes representatives native to Europe and Asia. The primary center of Paris diversity is China. Approximately 39 species of this genus have been identified throughout the world ( $\mathrm{Li}$ et al., 1998; Liang and Soukup, 2000), and 24 species are distributed in China (12 endemic plants) (Li, 1986). The particular characteristics of Paris are their 3-8 tepals that are in 2 whorls, the outer green, oval to lance-shaped, the inner line-shaped or sometimes missing. These herbaceous perennials grow in forests, including evergreen forests and bamboo forests. They are also found in thickets and scrub on river banks and in grass and rock canyons.

Some Paris species are used in traditional Chinese medicine for their analgesic and anticoagulant properties, most notably as an ingredient of hemostasis "Yunnan Baiyao" from Paris polyphylla var. chinensis. Intense ethnopharmaceutical interest has significantly reduced their numbers, such that wild $P$. polyphylla var. chinensis is on the edge of extinction in the last few decades. This plant grows to $40-130 \mathrm{~cm}$ tall with 5 to 10 leaves. The inner tepals are shorter than the outer ones. It can be found in forests including bamboo forests and thickets at 2800-3000 $\mathrm{m}$ in large areas of China, Taiwan, Laos, Myanmar, Thailand, and Vietnam. This plant comes from the hills of Sichuan. The rhizomes of P. polyphylla var. chinensis have been used in traditional Chinese medicine for the treatments of hemostasis, parotitis and snake bite for a very long time. Recently, it has been reported that the medicinal components of $P$. polyphylla var. chinensis possess antitumor, antiinflammatory, antibacterial, and immunoregulatory activities (Ji et al., 2001; Wu et al., 2004).

DNA-based molecular markers have acted as versatile tools and have found their own place in various fields such as taxonomy, physiology, embryology, genetic engineering, and so on. They are no longer looked upon as simple DNA fingerprinting markers in variability studies or as mere forensic tools. Ever since their development, they have constantly been modified to enhance their utilizations and to be more and more important for the analyses of the genome and genetic diversity (Vieira et al., 2007; Gonçalves et al., 2009; Oliveira et al., 2010). Molecular markers permit us to make estimates of genetic diversity directly at the DNA level, reducing the interference of environmental factors (Cabral et al., 2011). Also, many markers are available for each genome, there are high levels of polymorphism, and they are free of pleiotropic effects (Leal et al., 2010). During recent decades, SSRs (simple sequence repeats), also known as microsatellites, have become the most popular source of genetic markers owing to their high reproducibility, multi-allelic nature, codominant inheritance, high abundance, and wide genome coverage (Sharma et al., 2007; Demir et al., 2010; Cabral et al., 2011). The high information content in SSR loci, together with their codominant expression, make SSRs ideal for genomic 
mapping, population genetics, conservation biology, marker-assisted selection, and other studies (Roa et al., 2000; Ellegren, 2004; Schlötterer, 2004; Leal et al., 2010).

Although the morphology of $P$. polyphylla var. chinensis has been extensively studied, information about its molecular phylogeny and population genetics is very scarce. Original microsatellite loci have not been developed for any species of Paris. Here, we report the isolation and characterization of 12 polymorphic microsatellite loci from P. polyphylla var. chinensis using a biotin-capture method (Bloor et al., 2001), and the analysis of the genetic diversity of $P$. polyphylla var. chinensis using SSR molecular markers.

\section{MATERIAL AND METHODS}

\section{Plant materials and DNA extraction}

A total of 30 individuals of $P$. polyphylla var. chinensis were collected from a natural population in the south of Anhui Province. Leaves were collected and dried on silica gel in sealed polyethylene bags and stored at room temperature until genomic DNA was extracted. Genomic DNA was extracted using the standard cetyltrimethylammonium bromide (CTAB) method with some modifications (Doyle and Doyle, 1987).

\section{SSR analysis}

About 500 ng genomic DNA was digested by Sau 3AI (TaKaRa), and the fragments ranging from 400 to $900 \mathrm{bp}$ were purified and ligated to the Sau 3AI adaptors oligo A (5'-GGCCAGAGACCCCAAGCTTCG-3') and oligo B (5'PO4-GATCCGAAGCTTG GGGTCTCTGGCC-3') (Bloor et al., 2001). DNA fragments were amplified by polymerase chain reaction $(\mathrm{PCR})$ using oligo $(\mathrm{A})$ primers.

The products were then hybridized to the single-stranded 3'-biotinylated (CT) ${ }_{12}$ oligonucleotide probes and captured by streptavidin-coated beads (Promega). Enriched fragments were amplified and ligated to pMD19-T vector (TaKaRa). The recombinant plasmid was transformed into Escherichia coli DH5 $\alpha$ and the transformants were distinguished by blue-white screening. PCR using oligo (A) and (CT) $)_{12}$ oligonucleotides as the primers was employed to identify insert-positive clones. The clones that yielded two or more bands contained microsatellite fractions.

In total, 84 positive colonies were selected and sequenced on the ABI-PRISM 3730 automated sequencer (Applied Biosystems), and 55 contained repeat motifs. Fifty-one pairs of primers were designed using the PRIMER PREMIER 5.0 (http://www.premierbiosoft.com/) software and synthesized.

Sixteen sets of primers that gave consistent and specific PCR products were tested for allelic polymorphism in 30 individuals of a natural population in the south of Anhui Province. PCR amplifications were performed in a final volume of $12.5 \mu \mathrm{L}$ containing $6.25 \mu \mathrm{L} \mathrm{GoTaq}{ }^{\circledR}$ Green Master Mix (Promega), 0.1-1.0 $\mu \mathrm{M}$ of each primer and 10-20 ng DNA. The PCR conditions were $4 \mathrm{~min}$ at $94^{\circ} \mathrm{C}$ followed by 35 cycles of $45 \mathrm{~s}$ at $94^{\circ} \mathrm{C}, 35 \mathrm{~s}$ at optimized annealing temperature (Table 1) and $30 \mathrm{~s}$ at $72^{\circ} \mathrm{C}$, with a final extension time of $8 \mathrm{~min}$ at $72^{\circ} \mathrm{C}$. PCR products were separated on an $8 \%$ denaturing polyacrylamide gel using a LI-COR 4200 automated DNA sequencer and analyzed using the LI-COR SAGA ${ }^{\mathrm{GT}}$ software. 


\section{Data analysis}

The population genetic parameters number of alleles $\left(N_{\mathrm{A}}\right)$ per locus, observed $\left(H_{\mathrm{O}}\right)$ heterozygosity and expected $\left(H_{\mathrm{F}}\right)$ heterozygosity were determined with the GENETIX 4.05 software (Belkhir et al., 2001). Hardy-Weinberg equilibrium (HWE) and linkage disequilibrium (LD) were tested using GENEPOP version 4.0 (Raymond and Rousset, 1995). MICRO-CHECKER version 2.2.3 (van Oosterhout et al., 2004) was used to determine the presence of null alleles.

\section{RESULTS AND DISCUSSION}

Microsatellite markers in P. polyphylla var. chinensis had not previously been available. In this study, 12 polymorphic microsatellite loci of this plant were isolated, indicating that they can be powerful tools for the genetic study and gene flow analysis of P. polyphylla var. chinensis. The 12 sequences containing microsatellite loci were deposited in GenBank (JF707962-JF707973). The results are shown in Table 1.

\begin{tabular}{|c|c|c|c|c|c|c|c|c|}
\hline Locus & Primer sequence $\left(5^{\prime}-3^{\prime}\right)$ & Repeat motif & $\mathrm{Ta}\left({ }^{\circ} \mathrm{C}\right)$ & $\begin{array}{l}\text { Size range of } \\
\text { alleles (bp) }\end{array}$ & $N_{\mathrm{A}}$ & $H_{\mathrm{O}}$ & $H_{\mathrm{E}}$ & GenBank \\
\hline$P p 1^{*}$ & $\begin{array}{l}\text { F: TATCGCCTTCCTTCCAAT } \\
\text { R: GAATCTGTATGTCGCATCACT }\end{array}$ & $(\mathrm{CT})_{30}$ & 57 & $274-330$ & 3 & 0.133 & 0.406 & JF707962 \\
\hline$P p 2$ & $\begin{array}{l}\text { F: TTCTTTCAACCGCCATACCGT } \\
\text { R: TGCTTTGCTGCTTCTAACTCG }\end{array}$ & $(\mathrm{GA})_{19}$ & 59 & $264-292$ & 2 & 0.367 & 0.463 & JF707963 \\
\hline$P p 3^{*}$ & $\begin{array}{l}\text { F: AATACTCCGACGGGTGTTG } \\
\text { R: AGCGATAGCCAGAGGAAAGG }\end{array}$ & $(\mathrm{AG})_{26}$ & 63 & $230-264$ & 4 & 0.000 & 0.383 & JF707964 \\
\hline Pp4 & $\begin{array}{l}\text { F: ATCTCGTTGTCCCACCTTC } \\
\text { R: GTCGCTTGTCGGATTTCAG }\end{array}$ & $(\mathrm{TC})_{21}(\mathrm{TATC})_{6}$ & 63 & $300-342$ & 2 & 0.333 & 0.442 & JF707965 \\
\hline Pp 5 & $\begin{array}{l}\text { F: TCCACCTCCCTCGCCTCT } \\
\text { R: CGCAACAACAATGGTTCCCT }\end{array}$ & $(\mathrm{TG})_{16}(\mathrm{AG})_{30}$ & 63 & $244-312$ & 4 & 0.433 & 0.628 & JF707966 \\
\hline$P p 6^{*}$ & $\begin{array}{l}\text { F: CGCCATTAGGACAGGGATTCAC } \\
\text { R: TCTACTTTGCTGCGGCTCCAC }\end{array}$ & $(\mathrm{AG})_{16}$ & 63 & $262-282$ & 3 & 0.300 & 0.662 & JF707967 \\
\hline$P p 7^{*}$ & $\begin{array}{l}\text { F: GCAGGTATTCATCGCTTCT } \\
\text { R: CGATGGACTATGTGGAGACT }\end{array}$ & $(\mathrm{CT})_{21}(\mathrm{CA})_{7}$ & 61 & $182-236$ & 5 & 0.067 & 0.659 & JF707968 \\
\hline$P p 8$ & $\begin{array}{l}\text { F: ACCGTCATTTAGTTGGTGCGAG } \\
\text { R: TGTGAACGCCTTGGAACCCT }\end{array}$ & $(\mathrm{TC})_{17}(\mathrm{TCCC})_{3}$ & 63 & $228-264$ & 4 & 0.433 & 0.587 & JF707969 \\
\hline$P p 9^{*}$ & $\begin{array}{l}\text { F: GTGAGA AAACAACATGAA AGA } \\
\text { R: ACATCCCAGTATGACAGACG }\end{array}$ & $(\mathrm{GA})_{22}$ & 61 & $162-186$ & 3 & 0.067 & 0.566 & JF707970 \\
\hline Pp10 & $\begin{array}{l}\text { F: GACGATGAGTTCACGACGCTG } \\
\text { R: GTGTTTCGCTCACCAAGGACG }\end{array}$ & $(\mathrm{CT})_{23}$ & 63 & $170-218$ & 3 & 0.300 & 0.479 & JF707971 \\
\hline Pp11 & $\begin{array}{l}\text { F: AGCCTGATCGGTATTGTCGG } \\
\text { R: CCACGCCCTTTCCTTCTTTA }\end{array}$ & $\mathrm{A}_{5}(\mathrm{GA})_{24}$ & 63 & $178-194$ & 3 & 0.467 & 0.561 & JF707972 \\
\hline Pp12* & $\begin{array}{l}\text { F: ATGGAGCCCACCCTTGACGT } \\
\text { R: AACACCGCTTGACACCCGAC }\end{array}$ & $(\mathrm{GA})_{25}$ & 64 & $164-192$ & 4 & 0.067 & 0.602 & JF707973 \\
\hline
\end{tabular}

$N_{\mathrm{A}}=$ number of alleles; $H_{\mathrm{O}}$ and $H_{\mathrm{E}}=$ observed and expected heterozygosities; Ta = optimal annealing temperature. $*$ Significant deviation from Hardy-Weinberg equilibrium $(\mathrm{P}<0.05)$.

A total of 40 alleles were identified from 30 samples, and the number of alleles per locus ranged from 2 to 5. The largest number of alleles was found at the $P p 7$ locus, comprising 5 alleles, and the smallest number of alleles was found at the $P p 2$ and $P p 4$ loci, comprising 2 alleles. The average number of alleles per locus was 3.33 (Table 1).

$H_{\mathrm{O}}$ ranged from 0.000 to 0.467 with an average of 0.247 , and $H_{\mathrm{E}}$ ranged from 0.383 to 0.662 with an average of 0.537 (Table 1). For all loci analyzed, the average $H_{\mathrm{O}}$ was 2-3 times 
lower than the average $H_{\mathrm{E}}$, suggesting that self-pollination may be more common than usually assumed in P. polyphylla var. chinensis, but an excess of homozygotes may also result from sub-population (Wahlund effect). Population genetics theory predicts that a bottleneck causes a strong decrease in allelic richness and a more limited decrease in the $H_{\mathrm{E}}$ at neutral loci, as rare alleles are more readily affected by drift than are frequent alleles (Nei et al., 1975).

The deviations from HWE expectation for each locus were detected using the GENEPOP program (Raymond and Rousset, 1995) and a Bonferroni's correction for multiple tests (Table 1). Significant deviations from HWE expectations were found at loci $P p 1, P p 3$, $P p 6, P p 7, P p 9$, and $P p 12(\mathrm{P}<0.05)$, which may have resulted from a small population size associated with a bottleneck population or small founder population, although inbreeding or null alleles may also contribute to heterozygote deficiency. The LD among all loci within the population was also calculated. Five of the pairwise comparisons ( $P p 1$ and $P p 4, P p 2$ and $P p 5$, $P p 2$ and $P p 9, P p 2$ and $P p 12, P p 11$ and $P p 12)$ exhibited significant LD $(\mathrm{P}<0.05)$.

Besides, microsatellite loci $P p 4$ and $P p 8$ with a tetranucleotide core showed fewer polymorphisms, which may be due to lower mutation rates when compared with dinucleotides (Chakraborty et al., 1997). The low level of polymorphism was possibly caused by heterozygote deficiency resulting from inbreeding or sampling related individuals. Thus, larger natural populations will be necessary for further investigations.

Twelve microsatellite markers described here are the first set of microsatellites for $P$. polyphylla var. chinensis, most of which will be not only valuable for exploring population genetic structure and mating mechanism of this species but also for designing effective conservation strategies and taking appropriate measures for this wild medicinal plant.

\section{ACKNOWLEDGMENTS}

Research supported by the National Natural Science Foundation of China (\#30870062, \#31040003 and \#31170005), the Specialized Research Fund for the Doctoral Program of Higher Education of China (\#20113424110004), the Scientific Research Foundation for Returned Overseas Chinese Scholars from State Education Ministry, the Key Laboratory of Biotic Environment and Ecological Safety in Anhui Province, and the Program for Innovative Research Team in Anhui Normal University.

\section{REFERENCES}

Belkhir KP, Borsa P, Chikhi L, Raufaste N, et al. (2001). GENETIX, Logiciel Sous WindowsTM Pour la Génétique des Populations. Laboratoire Génome, Populations, Interactions CNRS UMR 5000. Université de Montpellier II, Montpellier.

Bloor PA, Barker FS, Watts PC, Noyes HA, et al. (2001). Microsatellite Libraries by Enrichment. Available at [http:// www.genomics.liv.ac.uk/animal/MICROSAT.PDF]. Accessed January 2002.

Cabral PD, Soares TC, Lima AB, de Miranda FD, et al. (2011). Genetic diversity in local and commercial dry bean (Phaseolus vulgaris) accessions based on microsatellite markers. Genet. Mol. Res. 10: 140-149.

Chakraborty R, Kimmel M, Stivers DN, Davison LJ, et al. (1997). Relative mutation rates at di-, tri-, and tetranucleotide microsatellite loci. Proc. Natl. Acad. Sci. U. S. A. 94: 1041-1046.

Demir K, Bakir M, Sarikamis G and Acunalp S (2010). Genetic diversity of eggplant (Solanum melongena) germplasm from Turkey assessed by SSR and RAPD markers. Genet. Mol. Res. 9: 1568-1576.

Doyle JJ and Doyle JL (1987). A rapid DNA isolation procedure for small quantities of fresh leaf tissue. Phytochem. Bull. 19: $11-15$.

Ellegren H (2004). Microsatellites: simple sequences with complex evolution. Nat. Rev. Genet. 5: 435-445. 
Goncalves LS, Rodrigues R, do Amaral Junior AT, Karasawa M, et al. (2009). Heirloom tomato gene bank: assessing genetic divergence based on morphological, agronomic and molecular data using a Ward-modified location model. Genet. Mol. Res. 8: 364-374.

Ji S, Zhou TS and Chang CJ (2001). Determination of anti tumor cytotoxic active substance gracillin in Rhizoma Paridis and yunnan white. Chin. Tradit. Patent Med. 23: 212-215.

Leal AA, Mangolin CA, do Amaral ATJ, Goncalves LS, et al. (2010). Efficiency of RAPD versus SSR markers for determining genetic diversity among popcorn lines. Genet. Mol. Res. 9: 9-18.

Li H (1986). A study on the taxonomy of the genus Paris L. Bull. Bot. Res. 6: 109-144.

Li H, Yang X, Liang H, Wei Z, et al. (1998). The Genus Paris (Trilliaceae). Science Press, Beijing.

Liang SY and Soukup VG (2000). Paris L. In: Flora of China (Wu ZY and Raven PH, eds.). Vol. 24. Science Press, Beijing, Missouri Botanical Garden Press, St. Louis.

Nei M, Maruyama T and Chakraborty R (1975). The bottleneck effect and genetic variability in populations. Evolution 29: $1-10$.

Oliveira EC, Amaral Junior AT, Goncalves LS, Pena GF, et al. (2010). Optimizing the efficiency of the touchdown technique for detecting inter-simple sequence repeat markers in corn (Zea mays). Genet. Mol. Res. 9: 835-842.

R aymond M and Rousset F (1995). GENEPOP (Version 1.2): population genetics software for exact tests and ecumenicism. J. Hered. 86: 248-249.

Roa AC, Chavarriaga-Aguirre P, Duque MC, Maya MM, et al. (2000). Cross-species amplification of cassava (Manihot esculenta) (Euphorbiaceae) microsatellites: allelic polymorphism and degree of relationship. Am. J. Bot. 87: 1647-1655.

Schlötterer C (2004). The evolution of molecular markers - just a matter of fashion? Nat. Rev. Genet. 5: 63-69.

Sharma PC, Grover A and Kahl G (2007). Mining microsatellites in eukaryotic genomes. Trends Biotechnol. 25: 490-498.

van Oosterhout C, Hutchinson WF, Wills DPM and Shipley P (2004). MICRO-CHECKER: software for identifying and correcting genotyping errors in microsatellite data. Mol. Ecol. Notes 4: 535-538.

Vieira EA, Carvalho FIF, Bertan I, Kopp MM, et al. (2007). Association between genetic distances in wheat (Triticum aestivum L.) as estimated by AFLP and morphological markers. Genet. Mol. Biol. 30: 392-399.

Wu SS, Gao WY, Duan HQ and Jia W (2004). Advances in studies on chemical constituents and pharmacological activities of Rhizoma paridis. Chin. Tradit. Herb. Drugs. 3: 344-347. 